\title{
Die Neandertaler und wir
}

Erhard Taverna

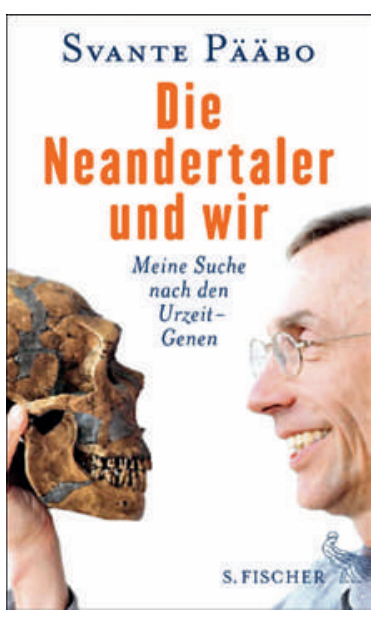

Svante Pääbo

Die Neandertaler und wir

Frankfurt a. M.: Fischer Verlag; 2014

384 Seiten. 34.90 CHF.

ISBN 978-3-1006-0520-7

erhard taverna[at]saez.ch
Im späten Pleistozän vermischten sich mehrere Menschentypen, wobei das genetische Rezept zur Herstellung eines modernen Menschen nicht sehr lange ist. Geschätzte 100000 Positionen in der DNASequenz unterscheiden ihn vom Neandertaler.

Der 1955 geborene Schwede Svante Pääbo und sein Team berichteten im Mai 2010 im Fachmagazin «Science» über die vollständige Sequenzierung des Neandertalergenoms. Der Spezialist für die Genomsequenzierung ausgestorbener Tierarten beschreibt in seiner Biografie «Die Neandertaler und wir» seine jahrzehntelange Suche nach den Urzeitgenen unseres entwicklungsgeschichtlich nächsten Verwandten. Der Gründungsdirektor der Abteilung evolutionäre Genetik am Max-Planck-Institut für evolutionäre Anthropologie in Leipzig begründete die Paläogenetik. Sohn eines Nobelpreisträgers, interessierte er sich schon als Kind für die Altertumsforschung, studierte Ägyptologie und später Medizin, was ihn über die klinische Virologie zur Molekularbiologie führte. Sein auch für Laien verständlich geschriebenes Buch schildert die komplexe internationale Zusammenarbeit von Archäologen, Bioinformatikern, Zoologen, Populationsgenetikern und vielen technischen Berufen, die unsere Kenntnisse der Vorgeschichte revolutioniert hat. Auf eine sehr persönliche Weise erzählt Svante Pääbo von Niederlagen, Konkurrenz und Teilerfolgen, die Schritt für Schritt neue Forschungswege erschlossen. Wir erfahren eine Menge über die Haltbarkeit und Gewinnung von DNA, die aufreibende Suche nach geeigneten Knochen, das zentrale Problem der Verunreinigungen und die rasante Entwicklung technischer Hilfsmittel wie PCR und Sequenzierautomaten. Nach heutigem Wissen haben sich moderne Menschen einer ersten Wanderbewegung aus Afrika mit ansässigen Neandertalern im nahen Osten vor 50000 bis 100000 Jahren vermischt. Etwa 2,5\% des Genoms der Menschen ausserhalb Afrikas stammen vom Neandertaler. Ein späterer Genfluss brachte den PapaNeuguineern einen Anteil von 4,8\% der, 2011 vom gleichen Team sequenzierten, Denisova-DNA.

Wie geht es weiter? 2002 wurde in Leipzig ein Gen namens FOXP2, das ein für die Sprachfähigkeit wichtiges Protein codiert, auf Mäuse übertragen. Das Programm heisst Zellstrukturen «vermenschlichen» oder «verneandertalern», um biochemische Unterschiede aufzuspüren. Gemäss Medienberichten soll das Mammut in Südkorea geklont werden. Vom Neandertaler spricht noch niemand. 